\title{
Implementing traditional performance management in the innovative age: A new model for Botswana's public sector
}

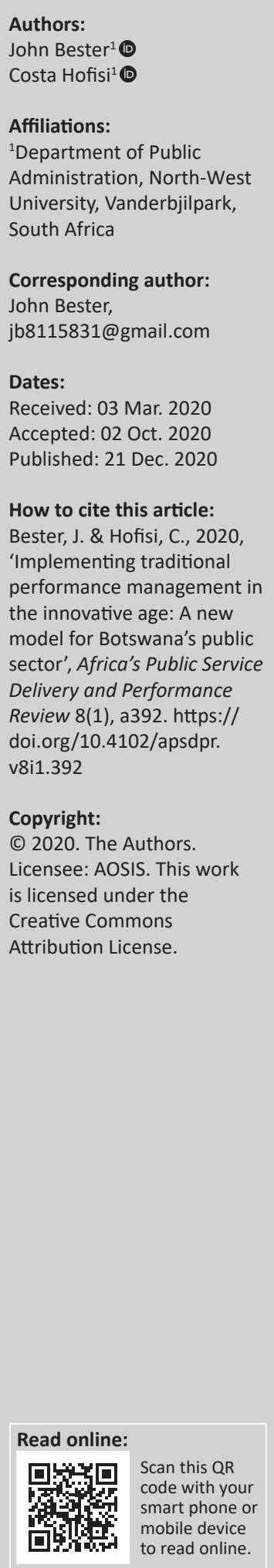

Background: Public statements on the deteriorating quality of public service in Botswana resulted in the implementation of performance management systems (PMS) in 1999 to restore the public's confidence in the ability of the public service to deliver quality service. However, this has not yielded the required results as student performance and service provision continue to decline.

Aim: This theoretical article is aimed at developing a performance management model that would replace the current one which has failed to motivate employees to improve performance.

Setting: The study was located within the innovation theory and focused on the two biggest ministries in Botswana, namely, local government and the education ministry.

Methods: The grounded theory was used to collect data through the mixed approach. Purposive sampling was used to select 80 employees, with each ministry providing 40 participants. Participants from the local government ministry work at headquarters and 30 participants of the education ministry also work at headquarters with the other 10 working as school managers.

Results: Findings of the study revealed that the current model had the following challenges in motivating employees to improve performance: lack of incentives, amount of paperwork and complexity of forms, relevance of information on performance development plan forms, the five-point rating scale and the performance review meetings.

Conclusion: The current model has failed to motivate employees because it lacks performance incentives and focuses on rating employees instead of improving employee performance through coaching. The Public Service Integrated PMS is proposed.

Keywords: public sector; model; performance management; Botswana; rating scale; performance improvement.

\section{Introduction}

An effective design and implementation of a performance management system (PMS) in the public sector is intended to motivate employees to improve performance and restore the public's confidence in the ability of the public service to deliver quality service. However, the implementation of the PMS in Botswana has not yielded the required results as student performance and service provision continue to decline. This research responds to the need to examine as to why the implementation of performance management in the public sector in Botswana has not yielded the expected results of improved employee performance.

\section{Research purpose and key questions}

The purpose of the research was to examine the perceptions and experiences of the concept and implementation of PMS by public officials in local government and the education ministry in Botswana in order to design an innovative performance management model in the public sector.

\section{Objectives of the study}

- To examine the perceptions and experiences of the concept and implementation of PMS by public officials in local government and the education ministry in Botswana.

- To develop an effective performance management model in the public sector in Botswana. 


\section{Research methods and design}

The study adopted the grounded theory (Birks \& Mills 2015) that is perceived as an appropriate and robust approach for the purpose of inductively generating theory in research (Tie, Birks \& Francis 2019:1-8). The rationale for using this research strategy is the need for an inductive theory development focusing on concerns of key actors, how the actors are experiencing the implementation of PMS and why the implementation of performance management has not motivated public-sector employees in Botswana to improve their performance. The study method seeks to discover experiences, perceptions and reactions of actors towards the concept and process of PMS implementation. Two ministries, namely, the local government ministry and the education ministry, were used to collect data using both quantitative and qualitative methods because both data generation techniques can be used in a grounded theory study (Holton \& Walsh 2016; Shim et al. 2017:27-40; Tie et al. 2019; Walsh 2015:1-27). In this study, the mixed methods approach was adopted to enrich and improve the understanding of the phenomenon under study and provide answers to questions that may be difficult to answer using a single classical method (Lund 2012: 155-169).

The population of the study consisted of officials of the two ministries who work at head office and the school managers of the education ministry. The rationale for choosing employees from the headquarters was that the top managers of the two ministries are based at headquarters from where the performance management initiatives originate. School managers were included on the basis of their experience as implementers of performance management. Purposive sampling was used to collect data from 80 respondents comprising 40 officials who work at the headquarters of the local government ministry, 30 officials who work at the headquarters of the education ministry and 10 school managers. One of the advantages of purposive sampling is that it allows the researcher to select individuals who are likely to be more informed and can provide more insights; and participants are, therefore, included on the basis of their experience of particular phenomena (Abrams 2010:536550; Riley \& Love 2000:164-187). The selected participants were involved in coordinating performance management activities in the two ministries.

Data were collected through the interview method, a focus group discussion and through questionnaires from each ministry. The interview technique was used because it is a flexible and adaptable way of collecting data (Robson 2002). The face-to-face interview technique was used because it offers the possibility of modifying one's line of enquiry, following up interesting responses and investigating underlying motives in a way that other techniques do not offer (Robson). Non-verbal cues may provide messages that assist the researcher to understand the verbal response, possibly changing or even in extreme cases reversing its meaning (Robson). Ten participants were interviewed. Each focus group had six participants. Focus group discussions can generate data that would be difficult to obtain without the discussion that takes place in a group context (Robson). Advantages of using a questionnaire are that it can reach a large sample, is inexpensive to administer, can be completed anonymously by the respondents and more information can be gathered.

Qualitative data were analysed to identify key themes following a number of stages that included assembling the data, getting an intuitive feel of it, open coding, axial coding, selective coding as well as refining and relating themes to develop insights from the point of view of the participants (Braun \& Clarke 2006:77-101; Conaway \& Wardrope 2010:141-168). Quantitative data were analysed to identify statistical relationships between variables to enhance the generalisation of the results and also allow for greater objectivity and accuracy of results (Robson 2002). Responses from questionnaires were presented in juxtaposition with responses from interviews and focus group discussions in order to bring wholeness to the data instead of presenting the data as discrete units. Theoretical sampling on the codes and categories of data was used to identify and follow clues from the analysis to fill gaps, clarify uncertainties and test interpretations (Birks \& Mills). This was to ensure that data contribute to theory development by working with concepts already compiled through a measure of fit and relevance (Pulla 2016:75-81).

\section{Review of literature}

The review of literature will examine the key components in the development of a PMS, examine challenges in the implementation of traditional PMS and explore the concepts of innovation and 'model'.

\section{Development of a performance management system}

Bulawa (2013:56-67) argues that the development of a PMS is not easy, which in turn can be guided by the following suggestions (Dobson 2001:199-210):

- A clear organisational strategy with well-designed objectives and performance measures that can be used for the formulation of employee performance expectations and performance evaluation.

- An effective management team at the top of an organisation with a clear vision and a strong will to guide the organisation through the change process and create an enabling environment for improved employee performance.

- The reasons for introducing performance management should be understood by both management and subordinates with both parties willing to play their part and take the responsibility of ensuring implementation success.

- The realisation that effective communication between managers and subordinates will result in employee motivation leading to improved performance and achievement of organisational goals. 
- Linking performance to rewards as a way of motivating employees to improve performance and send a message to employees that improved performance that leads to the achievement of goals is the ultimate goal of the organisation hence the rewards.

\section{Challenges in implementation of traditional performance management system}

The message from organisational research and practice is loud and clear: traditional performance management methods have challenges in engaging, motivating and driving productivity in today's employees (Bersin 2013; De Wall 2013:688-697; Ramirez 2013). Various challenges confronting the public service to implement effective performance management have been identified in studies that have been conducted, and the challenges include amongst others reform fatigue, resistance to change, inadequate resources, lack of incentives and the exclusion of implementers in the initial stages (Bulawa 2014:1-14; Dzimbiri 2008:43-58). The failure by employees to improve performance could be attributed to other challenges such as the current performance management model. The model seems not to have been embraced by employees in the public sector because of the resistance of the PMSs by employees in the public sector (Bulawa). The introduction of performance management should not be blamed for the current state of poor service delivery, but the public sector should draw lessons on what went wrong and how that can be corrected to ensure that performance management yields the expected results.

The introduction of performance management in the public sector in Botswana in 1999 was meant to improve employee performance that would result in improved service delivery. However, service delivery has not improved (Dzimbiri 2008:43-58), and questions may be asked whether the model that has been in use is effective in motivating employees. There might be a need to revisit the model and come up with an alternative model that would achieve the required outcomes. Performance management has been effective in improving service delivery in countries such as the United States of America, the United Kingdom and New Zealand (Dzimbiri). The Botswana government hoped that the introduction of an alternative innovative performance management model would make citizens regain confidence in the ability of the public sector to deliver quality services. This has, however, not happened as evidenced by the continuous decline in the results of learners in public schools and the general decline in service delivery (Bulawa 2014:1-18).

\section{Rethinking performance management system as a form of public-sector innovation}

Recent studies in this area have suggested doing away with performance management ratings (Ramirez 2013; Rock, Davis \& Jones 2014) and come up with new processes that encourage supervisors and managers to give feedback more frequently to the performance of employees (Arringdale
2014). This new processes of performance management is a form of public-sector innovation intended to improve employee performance and organisational effectiveness. Innovation in the public sector is essential to improve public services and is no longer an optional luxury but a practice that needs to be institutionalised as a deep value. However, questions have been asked whether there is such a thing as public-sector innovation. Lynn (1997) argues that if publicsector innovation cannot be delineated and defined as a concept, then it will lose credibility because it has no meaning. The sad issue is that many seminars on innovation are filled with buzz words and woolly concepts that are not specific and lack empirical grounded propositions (Pollitt \& Bouckaert 2011). This is why in recent years there has been increased interest in attempting to conceptualise and measure public-sector innovation in a way that is scholarly and measurable, so that it becomes useful in public policymaking. Some activities are said to be in the public sector instead of the private sector because of the challenges involved in measuring them. There is a need for public-sector employees to work smarter rather than harder and innovative performance management can make that a reality.

\section{Definition of the concept 'model'}

The definition of the concept 'model' will be examined to see how these definitions can be appropriated and applied in the construction of the performance management model in this research.

The definition of the concept 'model' is influenced by what one wants to ascribe it to (Van der Waldt 2013:38-56). Mouton and Marais (1988) define the concept 'model' based on its heuristic function. The concept is said to originate from the Latin word 'modulus' meaning 'small scale' (Botha 1993). Knowledge and understanding of scientists are generally represented by models that are scientific (Shoemaker, Tankard \& Lasorsa 2004). Models can be created, verified and modified through science. Little (2000) views models as significant in scientific thinking as well as in solving practical problems. Davies and Lewis (1971) state that when scientists investigate the reasons for a phenomenon to behave in a certain way, the investigation leads to a theory building, so that a solution to a particular problem can be explained using the relationship between the phenomenon and the behaviour that is shown. Modern practices in social sciences use formal models to make useful predictions, understand and appreciate human experience (Lave \& March 1993:239-256).

The concept 'model' has been defined differently depending on the context in which it is used, and it can include structure and relationships amongst variables but at the same time may convey tentativeness and incompleteness (Liu 2012). Abdulghafar (2011) also notes that models suggest the existence of structure and relationships within variables. Bailey (1978) perceives a model as a presentation of a system that is somehow different from the actual system although its accuracy is good enough to avail information about the 
system. Quade (1989) views a model as standing in for reality, assuming that it represents reality. Thompson and Strickland (1995) also agreed with the view and defined it as the imagined simplification of phenomenon that is more complex. De Vos et al. (2005) and Abdulghafar (2011) agree that models of social science do not contain all the features of the modelled system but only those required for the investigation or research.

\section{Characteristics of models}

Characteristics of models include but are not limited to the following (Van der Waldt 2013:38-56): they are used to build theory; they generally fit the task; they stand in for reality; they direct inquiry; they make the presentation of a system easier; they tend to have a heuristic function; they show relationships amongst variables; they are not perfect and are not complete and they simplify explanations that may be difficult to understand.

Public management literature gives a variety of meanings to the concept 'model', and one can construct a typology of models. Mouton and Marais (1988) perceive a typology as a conceptual framework for grouping functions. A typology enables a researcher to analyse phenomena. De Vos et al. (2005) define a typology as a way of classifying phenomena through the use of common characteristics. The aim is to arrange concrete forms into conceptual groups. Models can be grouped into the following types:

- Models as theory-building mechanisms: Williams (2003) perceives a theoretical model as a way of moving from the abstract to the concrete, and Kerlinger (1978) suggests that a model originates from a theory; but in social science, models are generally first constructed and theory can be built eventually from the model.

- Models as metaphors or analogies: Bless, Higson-Smith and Kagee (2007) point out that in the field of science, an analogy is perceived as the relationship between a phenomenon or event that has been previously studied and another phenomenon or event that is similar to the one that has been studied but has not yet been studied.

- Models as ideal types: There is an argument that society needs a lot more from the social sciences than its contribution so far and should answer not only the question 'What is' but also the question 'How should it be' (Taagepera 2008). As a response to this question, De Vaus (1994) perceives ideal-type models as an excellent way of coming up with an outcome. In social sciences, this may include ethical perspectives such as models for good governance.

- Models as an approach: In the policymaking context, Dye (1995) views a model as an approach to the study of policy dynamics and says that models assist in making the thought process simple and clear, direct inquiry and suggest explanations for a particular policy-related phenomenon.

- Models as cases or scenarios: De Vos et al. (2005) argue that it is a good thing for a researcher to start a study with a model case or model scenario. The case or scenario could be a certain situation, person, action or an event to which the concept that is being studied is appropriate. The implication in such a study is that the model case becomes a hypothetical situation appropriate to the concept (Yin 2004).

- Models as conceptual frameworks: Two types of conceptual frameworks are found in literature. Mouton and Marais (1988) view a conceptual framework as an attempt to give structure to theory and models. Two types of conceptual frameworks are identified, namely, typologies and theories and models. A conceptual framework can then be understood as a broad system under which theories and models are built in research (Mouton \& Marais).

- Models as graphical presentations and visual aids: In its basic form, a model may refer to a graphical presentation of a process, function or system in the form of diagrams, tables, charts or figures (Van der Waldt 2013:38-56). In this instance, a model enables the reader to visually register and understand all the variables and relationships relevant to the research. Botha (1993) agreed that models could be in the form of simple diagrams that demonstrate a web of relationships between constructs.

\section{Theoretical framework}

This study is informed by the innovation theory. Lynn (1997) defines public-sector innovation as an original, disruptive and fundamental transformation of the core tasks of an organisation that changes deep structures permanently.

Mulgan and Albury (2003) define it as new ideas that work, and successful innovation is perceived as the creation and implementation of new processes, services and methods of delivery that result in improvement of outcomes, efficiency and effectiveness or quality. Innovation is associated with a significant impact on the operations of the public sector to increase public value. There are pressures for efficiency and improved performance, and the public sector has to be responsive to the needs and aspirations of citizens. The one-size-fits-all services are no longer desirable in a diverse and heterogeneous society that has rising expectations everyday (Albury 2005:51-56). Innovative performance management may influence the performance of an organisation positively resulting in customer satisfaction and organisational effectiveness (Walker 2004:675-685) through the use of best practices and coaching, resulting in the achievement of goals because of the improved employee performance (Boyne \& Chen 2007:455-47).

Most innovations in the public sector are not radical or systemic but are incremental changes that in other cases are relatively minor changes and adaptations to the existing processes or services to improve performance (Albury 2005:51-56). Although the diffusion of innovation in the public sector is generally slower or more difficult than the private sector, the sector is far from lacking in innovation (Albury). Experience has shown that unleashing the creative and inventive potential of people in organisations generally 
leads to an explosion of innovative ideas (Albury). Table 1 presents the examples of public-sector innovation.

The public-sector innovation approach will be used to analyse empirical data on perceptions of performance management in the public service and design of emerging performance management model. The innovation approach will include the following key elements:

- Inputs - new inputs to enable the innovation - enabling environment that includes management support and will and employee trust.

- Process - creation and implementation of new processes, services and methods of delivery that encourage supervisors and managers to give feedback more frequently to the performance of employees.

- Outputs - the new products and services to improve efficiency and improved employee performance.

- Outcomes - the improvement in effectiveness or quality.

- Impact - improved customer satisfaction and organisational effectiveness.

This research article will illustrate how innovation approach can be applied to design a new alternative model of performance management.

\section{Analysis of data and key findings}

In this section, the findings of the perceptions of respondents on the current performance management model are presented under the following categories: lack of incentives, amount of paperwork and complexity of forms, relevance of information in performance development plans, fivepoint rating scale and performance review meetings.

\section{Lack of incentives}

The participants were asked to indicate on a questionnaire whether the lack of incentives for good performance negatively affected the performance of employees. Table 2 shows that two respondents $(2.5 \%)$ agreed that the lack of incentives did not negatively affect the performance of employees, whilst 78 respondents (97.5\%) disagreed with the statement. It is evident from this that the absence of performance incentives for good performance negatively affects the performance of employees in the two ministries.

Related sentiments were also echoed by focus group discussants. A general feeling amongst most of the discussants $(80 \%)$ is that employees were of the view that government had not kept its promise of rewarding good performers as promised at the introduction of PMS. The discussants were of the view that lack of incentives to motivate employee performance was one of the weaknesses of the current model of performance management. The respondents indicated that it was not easy for managers in different departments to motivate employees to perform, and employees did not see the purpose of completing performance development plan forms if high performance was not rewarded. The following remarks were typical:

'During workshops managers often ask why government had not fulfilled what it said at the introduction of PMS that good performers would be rewarded. Managers often ask us what they should say to employees regarding the government promise.' (Participant A, Performance Management Coordinator, 24 July 2018)

'Trade unions constantly remind their members that government uses PMS to manipulate them without rewarding their efforts.' (Participant B, Performance Management Coordinator, 24 July 2018)

TABLE 2: Lack of performance incentives is not negatively affecting employees' performance.

\begin{tabular}{lcc}
\hline Variable & Frequency & $\mathbf{\%}$ \\
\hline Strongly agree & 0 & 0.0 \\
Agree & 2 & 2.5 \\
Strongly disagree & 60 & 75.0 \\
Disagree & 18 & 22.5 \\
\hline Total & $\mathbf{8 0}$ & $\mathbf{1 0 0 . 0}$ \\
\hline
\end{tabular}

TABLE 3: Amount of paperwork involved in performance management system is not overwhelming and the forms are easy to understand.

\begin{tabular}{lcc}
\hline Variable & Frequency & $\%$ \\
\hline Strongly agree & 0 & 0 \\
Agree & 4 & 5 \\
Strongly disagree & 56 & 70 \\
Disagree & 20 & 25 \\
\hline Total & $\mathbf{8 0}$ & $\mathbf{1 0 0}$ \\
\hline
\end{tabular}

TABLE 1: Types of public-sector innovation.

\begin{tabular}{|c|c|c|c|}
\hline Innovation type & Focus & References & Examples \\
\hline 1. Product or service innovation & Creates new public services or products & Damanpour and Gopalakrishnan (2009:650-675) & The establishment of youth disability benefits \\
\hline 2. Process innovation & $\begin{array}{l}\text { The improvement of quality and efficiency of } \\
\text { both external and internal processes }\end{array}$ & $\begin{array}{l}\text { Damanpour and Gopalakrishnan (2001: } \\
\text { 45-65); Walker (2014:675-685) }\end{array}$ & - \\
\hline Administrative process innovation & $\begin{array}{l}\text { Creates new organisational forms, introduces } \\
\text { new management methods and techniques } \\
\text { as well as new working methods }\end{array}$ & Daft 1978:15-27; Meeus and Edquist 2006 & $\begin{array}{l}\text { Creation of a 'one-stop shop' by a local } \\
\text { authority where the community can obtain } \\
\text { various services at one location }\end{array}$ \\
\hline Technological process innovation & $\begin{array}{l}\text { The creation or use of new technology to } \\
\text { render services to users and citizens }\end{array}$ & $\begin{array}{l}\text { Damanpour and Gopalakrishnan (2001: } \\
45-65) ; \text { Edquist (2001:1725-1753) }\end{array}$ & The digital assessment of taxes \\
\hline 3. Conceptual innovation & $\begin{array}{l}\text { Introducing new concepts, new paradigms or } \\
\text { frames of reference that assist to reframe the } \\
\text { nature of certain challenges and their possible } \\
\text { solutions }\end{array}$ & Bekkers, Edelenbos and Steinjn (2011) & $\begin{array}{l}\text { Introducing a paradigm where insurance } \\
\text { physicians assess the (dis)ability of an } \\
\text { individual by focusing on what the person can } \\
\text { do rather than what one cannot do }\end{array}$ \\
\hline 4. Governance innovation & $\begin{array}{l}\text { Developing new forms and processes for } \\
\text { tackling specific societal challenges }\end{array}$ & $\begin{array}{l}\text { Bekkers et al. (2011); Moore and Hartley } \\
(2008: 502-577)\end{array}$ & $\begin{array}{l}\text { Governance practices that try to enhance the } \\
\text { self-regulating and self-organising capacities of } \\
\text { policy networks }\end{array}$ \\
\hline
\end{tabular}

Source: De Vries, H.A., Bekkers, V.J.J.M. \& Tummers, L., 2014, 'Innovation in the public sector: A systematic review and future research agenda', In Proceedings at the Speyer: EGPA conference, Rotterdam, April 09-11, 2014, pp. 1-30

Note: Please see the full reference list of this article for more information. 
'Many managers have expressed their concern on the lack of implementing the incentive scheme which is in the performance management policy as a motivation strategy.' (Participant C, Performance Management Coordinator, 24 July 2018)

These sentiments indicate that employees are frustrated by the lack of incentives that would motivate them to perform. This suggests that performance is not likely to improve if employees have a negative attitude towards PMS.

\section{Amount of paperwork and complexity of forms}

The question of interest was to find the perception of employees on the amount of paperwork involved in performance management and the complexity of PMS forms. Table 3 shows that four respondents (5\%) agreed with the statement that the amount of paperwork involved in PMS was not overwhelming and the forms are easy to understand, whilst 76 respondents (95\%) disagreed with the statement. From the results, it is clear that the paperwork is overwhelming and the forms are not easy to understand. Interestingly, none of the 5\% who agreed with the statement strongly agreed with it.

Interviewees from the two ministries indicated that employees complained of the amount of paperwork involved in performance management. An interviewee from the education ministry had this to say:

'School managers complain that teachers were spending more time completing performance development plan forms robbing learners of contact time with the teachers. Managers also feel that they spend a lot of time going through completed forms instead of supervising teachers.' (Participant B, Performance Management Coordinator, 24 July 2018)

This was corroborated by focus group discussants who indicated that some employees in the departments were of the view that performance management was about paperwork as well as judging them. They revealed that some employees had come to the headquarters to complain about the lack of trust in the performance management model as they perceived it as an instrument that judged their performance instead of assisting them to improve performance. The discussants also revealed that the vocabulary used in the forms was challenging for some employees. They also indicated that the model was imported from the developed countries, and the forms had not been thoroughly revised to adapt them to the local situation; hence, it involved changes to procedures and vocabulary from time to time, and managers in the departments would

TABLE 4: Information in the performance development plans is relevant and assists in performance improvement.

\begin{tabular}{lcc}
\hline Variable & Frequency & $\mathbf{\%}$ \\
\hline Strongly agree & 2 & 2.50 \\
Agree & 5 & 6.25 \\
Strongly disagree & 42 & 52.50 \\
Disagree & 31 & 38.75 \\
\hline Total & $\mathbf{8 0}$ & $\mathbf{1 0 0 . 0 0}$ \\
\hline
\end{tabular}

raise these issues with the headquarters. A participant made the following remark:

'At a workshop one line manager asked if it was possible for the ministry of local government to come up with a model that was relevant to the local situation.' (Participant C, Performance Management Coordinator, 24 July 2018)

Spending more time in completing the forms negatively affects productivity. The complexity of the forms would also frustrate employees as they would have to spend time consulting management on how to complete the forms.

\section{Relevancy of information in performance development plans}

Participants were asked to indicate whether the information in the performance development plans was relevant and assisted employees to improve performance. Table 4 shows that seven respondents $(8.75 \%)$ agreed with the statement whilst 73 respondents $(91.25 \%)$ disagreed with the statement. When the same issue was followed up through the focus group discussions, the participants indicated that managers had raised the concern regarding the design of the performance development plans.

It emerged during the discussions that some of the information included in the forms were perceived as irrelevant and should be removed because they increased the volume of what had to be written on the forms, without adding value to the whole exercise. An example given by a participant was for the employee to comment on factors that contributed to organisation profit-making, indicating that the forms should have been revised to remove private-sector issues such as profit. The discussants indicated that during workshops managers had complained that performance had not improved because the performance management model was focused on rating the employees rather than performance improvement. Some interviewees were of the view that employees wanted to obtain a good score regardless of their performance. An interviewee had this to say:

'Managers have constantly asked if the emphasis should be on performance improvement or on getting a good rating score. The forms seem to put more emphasis on rating employee performance rather than performance improvement.' (Participant B, Performance Management Coordinator, 24 July 2018)

\section{Five-point rating scale}

Participants were asked to indicate whether managers were comfortable with the five-point rating scale (see Table 5).

TABLE 5: Managers in the departments are comfortable with the five-point rating scale.

\begin{tabular}{lcc}
\hline Variable & Frequency & $\mathbf{\%}$ \\
\hline Strongly agree & 4 & 5.00 \\
Agree & 7 & 8.75 \\
Strongly disagree & 56 & 70.00 \\
Disagree & 13 & 16.25 \\
\hline Total & $\mathbf{8 0}$ & $\mathbf{1 0 0 . 0 0}$ \\
\hline
\end{tabular}


On this issue, 11 respondents (13.75\%) agreed with the statement that managers were comfortable with the five-point rating scale whilst 69 respondents $(86.25 \%)$ disagreed with the statement. On the same issue, most of the interviewees (82\%) expressed their concern on the challenges that line managers faced in rating the employees because some of the categories were almost the same.

The focus group discussants revealed that during workshops managers have requested performance management coordinators to clearly explain the differences between the rating categories because of the challenges they face with subordinates when it comes to rating their performance. The following remark was made by a participant:

'At a workshop I was asked to differentiate between 'excellent' and 'outstanding' performance and it was not easy for me to respond. Such issues can be a challenge when a teacher requests for a clear explanation from their school manager.' (Participant C, Performance Management Coordinator, 24 July 2018)

From the foregoing remark, it is clear that the five-point rating scale can exert challenges on managers in choosing a category that is appropriate for the performance of an employee. The manager might also be asked by the employee to justify the choice of the category and this might not be easy. Issues of favouritism and mistrust of the system might arise because of the rating scale.

\section{Performance review meetings}

Participants were asked whether managers were comfortable with the current system where performance reviews were held three times in a year. Table 6 shows that 14 respondents $(17.5 \%)$ agreed with the statement whilst 66 respondents $(82.5 \%)$ disagreed with the statement. From these results, it is clear that managers were not comfortable with three performance review meetings per year.

In the open-ended section of the questionnaire, 20 respondents $(25 \%)$ expressed the view that employees would have forgotten what would have taken place in the previous months that could have affected their performance. This was corroborated by comments made by forum group discussants. The following remarks were typical:

'Some managers have submitted performance development forms that are not signed by the subordinate because the individual would argue that they could not recall things that happened 3 months ago and were not sure if the supervisor's comments were correct. This is usually the case if the individual employee was not satisfied with the rating and it creates mistrust

TABLE 6: Managers are comfortable with the current practice of three performance review meetings per year.

\begin{tabular}{lcc}
\hline Variable & Frequency & $\mathbf{\%}$ \\
\hline Strongly agree & 5 & 5.26 \\
Agree & 9 & 11.25 \\
Strongly disagree & 44 & 55.00 \\
Disagree & 22 & 27.50 \\
\hline Total & $\mathbf{8 0}$ & $\mathbf{1 0 0 . 0 0}$ \\
\hline
\end{tabular}

between the manager and the subordinate.' (Participant A, Performance Management Coordinator, 24 July 2018)

'Managers have indicated that review meetings were not productive because individual employees would argue that the manager was referring to performance challenges of the previous months which the individual could not recall and the employee would argue and say the performance challenge had since been overcome. Some managers have expressed their unwillingness to conduct review meetings because of these challenges.' (Participant B, Performance Management Coordinator, 24 July 2018)

\section{Discussion}

The present performance management model in the public sector in Botswana is not linked to rewards in practice (Dzimbiri 2008:43-58), although policy stipulates that good performance should be rewarded. This could be one of the reasons that have made the current model of performance management fail to motivate employees. Motivation is crucial in employee performance as proclaimed by the expectancy theory (Vroom 1964). If good performance is linked to incentives, employees are likely to be motivated because of anticipated or outcome expectances.

There is, therefore, a need to have a model that would motivate employees by rewarding good performance. In a study conducted by Bulawa (2014:1-18) in Botswana, school managers complained of lack of funds for effective performance management. Studies on the implementation of performance management in the public sector in Botswana have revealed that objectives of the performance reward system lacked goal clarity, performance targets, customer focus and employee role allocation, and in the end, implementation of the reward system did not materialise as originally planned (Kealesitse et al. 2013:33-55).

Innovative performance management can assist the public sector in Botswana to increase the efficiency and effectiveness of internal procedures and processes resulting in quality service provision. New challenges and demands for the public sector emerge from new and heightened expectations of improved service delivery from a customer base that is increasingly diverse in its perceptions on quality service. This calls for the public sector to be innovative because the environment in which the sector exists is not static and what seemed certain yesterday turns out to be rather different tomorrow.

In a study by Bulawa (2014:1-18), school managers in public schools in Botswana revealed that they had become managers of paper instead of managing people because of the paperwork they had to deal with in the implementation of performance management. The performance development plans that have to be completed by employees are voluminous, and employees have to spend a considerable time completing them. This also affects the time they need to spend performing their tasks. A study by $\mathrm{O}^{\prime}$ Brien and Down 
(2002:111-133) in Australia found that teachers complained of the amount of paperwork involved in the implementation of performance management, with documentation arising from management meetings, performance management and other issues associated with the accountability of the reform. Clinton, the former president of the United States, concurred with this finding and indicated that there was a need to conquer a mountain of paperwork that was crushing employees and wasting more resources (Radin 1998:307316). There is a need to implement an innovative model that does not overwhelm employees with paperwork, so that they spend most of their time at work performing their core tasks.

In a study by Bulawa (2013:56-67), school managers in public schools in Botswana perceived the complexity of completing forms for performance management as mind-boggling and too academic for the average employee. The paperwork was perceived as difficult to understand and complete, and managers had to spend more time trying to assist employees to complete the forms although they hardly understood how the forms should be completed (Bulawa). The perception amongst managers was that the amount of time spent on trying to complete the forms was counter-productive as it affected the time devoted to the core business of an organisation (Bulawa). Performance management system was perceived as a reform that has to do with paperwork than improve productivity because of the amount of time spent by employees completing forms that were complex to understand (Bulawa). The public sector should simplify performance development plans, so that employees can easily understand the forms and take less time in completing them.

Berman and Wang (2000:409-420) argue that more ground work should be performed before performance management can be fully and successfully implemented. This is critical in view of the challenges that may affect implementation. Literature on PMS states that successful implementation depends on the confidence of implementers; and if implementers lack confidence because they do not understand what they should do, then implementation becomes a challenge (Armstrong 2015). A study by Down (1999:213-223) in Australia revealed that teachers perceived the model of performance management that was being implemented with significant levels of scepticism, mistrust and anxiety, and they indicated that the implementation of the model was not working. Down also found that teachers perceived the appraisal used as having judged them falsely or inadequately and in the end did what their supervisors wanted to hear for the sake of satisfying them. The teachers did not trust the process of the model because they felt it did not build a spirit of trust, collegiality and respect (Down).

It emerged from the findings of this study that the five-point rating scale was a challenge because some of the categories were almost the same (see Table 7). The public service in Botswana uses a five-point rating scale in evaluating the performance of employees. The scale is used to assess the performance of employees around a central point, and this point is usually referred to as the acceptable performance
TABLE 7: Rating scale.

\begin{tabular}{|c|c|c|}
\hline \multicolumn{3}{|c|}{ Scale } \\
\hline 3 & 2 & 1 \\
\hline Outstanding performance & Excellent performance & $\begin{array}{l}\text { Performance is below } \\
\text { average }\end{array}$ \\
\hline $\begin{array}{l}\text { Performance always } \\
\text { exceeds expectations }\end{array}$ & $\begin{array}{l}\text { Performance exceeds } \\
\text { expectations at times }\end{array}$ & Targets are not met \\
\hline Performance is exemplary & Performance is very good & $\begin{array}{l}\text { Performance must be } \\
\text { improved }\end{array}$ \\
\hline One of the best performers & A highly effective performer & $\begin{array}{l}\text { An individual who needs to } \\
\text { improve }\end{array}$ \\
\hline $\begin{array}{l}\text { A top performer in the } \\
\text { department }\end{array}$ & An outstanding performer & $\begin{array}{l}\text { Targets proving to be a } \\
\text { challenge }\end{array}$ \\
\hline
\end{tabular}

Source: Bussin, M., 2013, The performance management handbook for emerging markets: A practical and informative handbook for managing performance for the world of work in emerging markets, Knowres Publishing (Pvt) Ltd, Johannesburg

(Bussin 2013). One of the weaknesses with the five-point rating scale is that it is rated as average performance when some objectives may not have been met (Bussin). At the review meeting, employees may argue that their performance was not average in a bid to request for a higher rating (Bussin). If the rating scale is composed of the following: outstanding, excellent, fully effective, needs improvement, and unacceptable, the challenge that a manager or supervisor may have is to decide whether the employee deserves the rating 'outstanding' or 'excellent'. It might not be easy to make a distinction between the two. A model that could be easier for management to make a decision should have a three-point rating scale, which is perceived to be easier for managers in decision-making regarding the performance of an employee (Bussin). A threepoint rating scale would assist managers in the public sector to be more objective in rating employee performance.

This study established that review meetings were not productive in improving employee performance because reviews were performed three times in a year. Employees did not seem to value the importance of review meetings; hence, they would not sign the forms as required. Armstrong (2015) argues that the performance review meeting provides an opportunity for the employee and the supervisor to focus on key performance and developmental issues. The meeting is an important stage in the cycle of performance management. It assists in updating the performance agreement and ensures that the five major elements, namely, agreement, feedback, assessment, positive reinforcement and dialogue are effectively carried out (Armstrong). Performance management should be an ongoing exercise throughout the year. The manager should regularly monitor outcomes against performance plans, and where necessary corrective action should be taken, rather than doing so after several months (Armstrong). For monitoring to be effective, managers should continuously give feedback, support and guidance. This will result in continuous learning on the job, which will eventually improve the performance. Continuous monitoring and feedback should be implemented in the public service, so that performance management focuses on performance improvement instead of rating employees.

\section{Proposed performance management model for the public sector in Botswana}

Based on the above empirical evidence and the key components of a PMS in literature review (see Section 


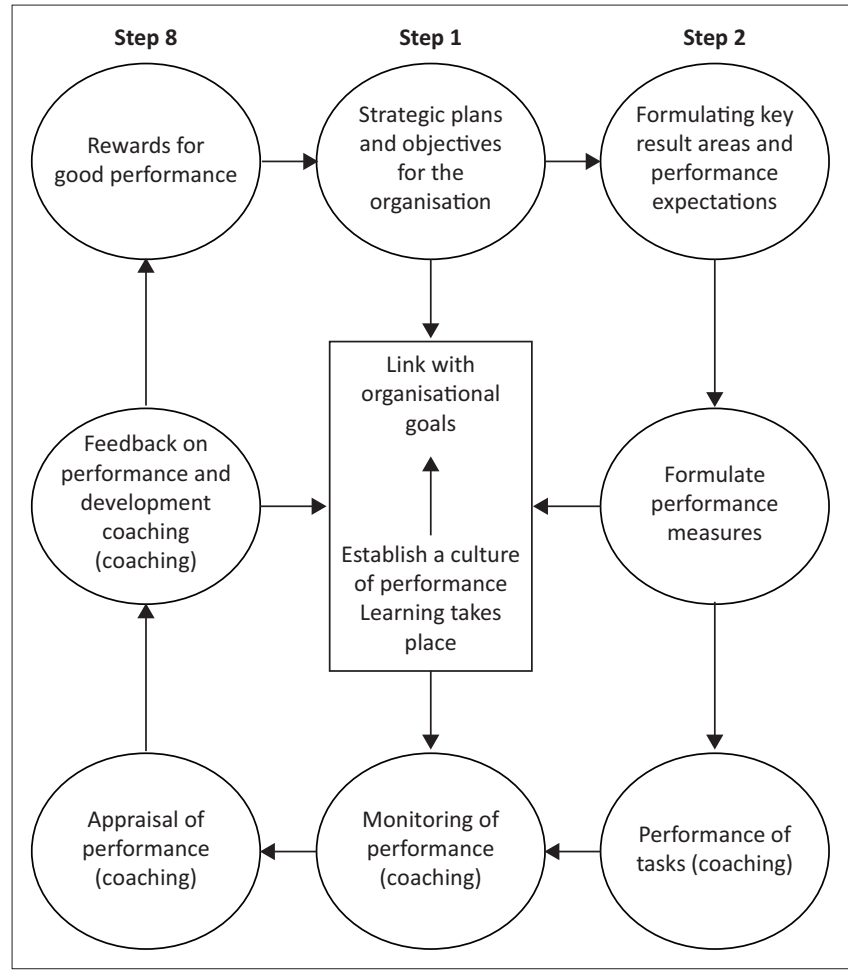

FIGURE 1: Proposed performance management model.

Development of a performance management system), the proposed model attempts to address the key failures of the current PMS.

The performance management model (see Section Definition of the concept 'model') will be seen as a process and graphical presentation; the proposed model will assist in making the thought process simple and clear, direct inquiry and suggest explanations for a particular policy-related phenomena. A performance management model can be viewed as a way in which an organisation integrates its performance with the strategies and objectives of the organisation (Mwita 2000:19-37). In the public sector, a model should be able to address strategic linkages with the performance of the organisation (Mwita). The Public Service Integrated PMS (PSIPMS) model is proposed for the public sector in Botswana. The model is made of eight steps, and if effectively implemented, it is likely to motivate employees leading to improved employee performance (Figure 1).

\section{Strategic plan}

\section{Step 1: Strategic plans and objectives for the organisation}

The model adopts a strategic approach to performance management by taking a broad view of where the public sector in Botswana wants to go, so that the management of performance is linked to the strategy of the sector. The strategy provides a direction that addresses the needs of the sector and employees through the development and implementation of an integrated system of management and employee development.

\section{Step 2: Key result areas and performance expectations}

The model adopts a performance planning of key result areas that involve both the manager and the individual employee. The profile of the employee is defined by both parties and they agree upon the key result areas. The profile includes the key results expected, what employees are expected to know and be able to do and the behaviour that is expected from them in terms of competencies.

\section{Step 3: Measurement of performance}

The manager and the employee agree on the performance measurement. The agreement should centre on the performance measurement of key result areas. The outcomes of key result areas are crucial in the achievement of individual and organisational goals; hence, the need to measure their attainment. The discussion between the manager and subordinate focuses on measurement in terms of outputs and outcomes. It should be understood by both parties that the measurement of an output focuses on quantity whilst that of an outcome focuses on a visible effect resulting from effort that cannot generally be measured in quantity terms (Armstrong 2009).

\section{Step 4: Performance of tasks}

At this stage, the model emphasises the need for the manager to provide enough resources that the employee can use to achieve set targets. When the employee has challenges regarding knowledge and skills in performing certain tasks, the manager provides full support, so that the employee is able to perform the tasks, and the support of the manager should be viewed as part of motivating the employee to achieve high performance.

\section{Step 5: Monitoring of performance}

The monitoring stage requires the manager to continuously discuss with the employee informally on how progress towards the set targets is progressing. Where the employee needs clarification, the management provides it. Coaching is provided by the manager to build on the strengths of subordinates as per the plan. Coaching is perceived as part of the development plan for employees to improve performance. During coaching meetings, issues such as career development and self-awareness are covered.

\section{Step 6: Performance appraisal}

The model adopts a meaningful appraisal approach that emphasises the importance of the needs of each employee and those of the organisation. It should not be perceived as a duty or meaningless chore, which has to be performed. The process should not be cumbersome and, therefore, negatively perceived. Both parties should look forward to it because of its benefits.

\section{Step 7: Feedback on performance and development}

The model adopts a positive performance management feedback that emphasises on development and improvement. 
The manager recognises the successes of the individual employee and where there is a need for performance improvement, a constructive discussion is recommended. During the performance review meeting, the emphasis should be on what could be performed to improve performance rather than blaming the employee for not achieving targets. The discussion should centre on results, events and behaviours that seem to affect performance, and suggestions on improvements are made.

\section{Step 8: Rewards for good performance}

The model recommends for a performance-related pay scheme for individual employees in the public sector in Botswana to enhance the relationship between performance and rewards. The performance-related pay scheme will be linked to the salary of the public service, the employee's grade and the performance rating of the employee. The available funds for the public service will also determine the rewards.

The model recommends a performance-related pay scheme to motivate employees to perform and send a clear message to employees that the public sector in Botswana rewards high performance. Policy should be implemented to reward good performance. Both management and employees would be involved in all the stages of implementation, with employees contributing their views. Managers should focus on employee coaching to improve employee performance.

\section{Theoretical propositions}

As the PSIPMS model is based on data collected, a number of theoretical propositions were developed that can explain how performance management results in improved employee performance:

- The involvement of employees in the design, formulation and implementation of PMS leads to positive employee perceptions of the model, resulting in employee motivation.

- Performance management implementation accompanied by meaningful rewards or incentives (monetary) for good performance leads to employee motivation and achievement of organisational goals.

- An imported performance management model needs adaptation to remove irrelevant information tosuit the local situation and environment in order for the model to be perceived as relevant.

- Excessive PMS paperwork and unproductive review meetings develop negative perceptions of PMS amongst employees, negatively affecting work engagement and achievement of organisational goals.

\section{The proposed performance management model as an example of public-sector innovation}

The proposed performance management model will ensure an enabling environment, management support and employee trust as key inputs to the system; with the creation and implementation of new processes, services and methods of deliver that encourage supervisors and managers to give feedback to the performance of employees more frequently; to produce new products and service outputs to improve efficiency; improved employee performance; that will contribute to yielding outcomes in the improvement of effectiveness or quality; and yield significant impact in the form of improved customer satisfaction and organisational effectiveness.

\section{Conclusion}

The current model in Botswana has failed to motivate employees to perform because of its focus on rating employees instead of coaching employees to improve performance. Weaknesses in the model include lack of incentives for good performance, excessive paperwork, complexity of forms, irrelevant information on performance development forms and unproductive review meetings. The study, therefore, concludes that the implementation of traditional performance management coupled with the lack of incentives is not likely to result in employee performance improvement. The proposed model, the PSIPMS, is collaborative in nature to develop a feeling of ownership amongst implementers, leading to positive perceptions on the model.

\section{Acknowledgements Competing interests}

The authors have declared that no competing interests exist.

\section{Authors' contributions}

All authors contributed equally to this work.

\section{Ethical consideration}

This article followed all ethical standards for a research without direct contact with human or animal subjects.

\section{Funding information}

This research received no specific grant from any funding agency in the public, commercial or not-for profit sectors.

\section{Data availability statement}

Data sharing is not applicable to this article as no new data were created or analysed in this study.

\section{Disclaimer}

The views and opinions expressed in this article are those of the authors and do not necessarily reflect the official policy position of any affiliated agency of the authors.

\section{References}

Abdulghafar, B.R., 2011, 'Model building and usage in social science research', in R.O. Lasisi \& J.O. Fayeye (eds.), Leading issues in general studies, humanities and social sciences, pp. 105-133, University of Ilorinn, Ilorinn. 
Abrams, L.S., 2010, 'Sampling "hard to reach" populations in qualitative research', Qualitative Social Work 9(4), 536-550. https://doi.org/10.1177/1473325010367821

Albury, D., 2005, 'Fostering innovation in public services', Public Money \& Managemen 25(1), 51-56.

Armstrong, M., 2009, Handbook of Human Resource Management Practice, Kogan Page, London.

Armstrong, M., 2015, Armstrong's handbook of performance management: An evidence based guide to delivering high performance, Kogan Page, London.

Arringdale, C., 2014, The case of more frequent performance reviews, SHRM Connect, viewed 25 September 2018, from http://community.shrm.org.

Bailey, K.D., 1978, Methods of social research, The Free Press, New York, NY.

Babbie, E. \& Mouton, J., 2011, The Practice of Social Research, Oxford University Press, Cape Town.

Bekkers, V., Edelenbos, J. \& Steijn, B., 2011, Innovation in the public sector, Palgrave, London.

Berman, E. \& Wang, X., 2000, 'Performance management in US counties: Capacity for reform', Public Administration Review 60(5), 409-420. https://doi.org/ 10.1111/0033-3352.00104

Bersin, J., 2013, Time to scrap performance appraisals? viewed 22 June 2018, from https://www.forbes.com/sites/joshbersin/2013/05/06/time-to-scrapperformance-appraisals/?sh=9cebeda31c36

Birks, M. \& Mills, J., 2015, Grounded theory: A practical guide, SAGE Publications, Thousand Oaks, CA.

Bless, C., Higson-Smith, C. \& Kagee, A., 2007, Fundamentals of social research methods: An African perspective, Juta, Kenwyn.

Botha, M.E., 1993, Metateoretiese perspektief op die sosiale wetenskappe [Metatheoretical perspectives on the social sciences], University Department Sential Publications, Potchefstroom.

Boyne, G. \& Chen, A., 2007, 'Performance targets and public service improvement', Journal of Public Administration Research and Theory 17(3), 455-477. https://doi. Journal of Public Administratior
org/10.1093/jopart/mul007

Braun, V. \& Clarke, V., 2006, 'Using thematic analysis in psychology', Qualitative ResearchinPsychology3(2),77-101.https://doi.org/10.1191/1478088706qp063oa

Bulawa, P., 2013, 'Constraints to senior management's capacity to implement the performance management system in senior secondary schools in Botswana', International Education Journal 6(5), 56-67. https://doi.org/10.5539/ies.v6n5p56

Bulawa, P., 2014, 'Impediments to senior management team's (SMT) role of implementing the performance management system (PMS) in senior secondary schools in Botswana', International Journal of Current Research and Academic Review 2(3), 1-18.

Bussin, M., 2013, The performance management handbook for emerging markets: A practical and informative handbook for managing performance for the world of work in emerging markets, Knowres Publishing (Pvt) Ltd, Johannesburg.

Conaway, R.N. \& Wardrope, W.J., 2010, 'Do their words really matter? Thematic analysis of U.S. and Latin American CEO letters', Journal of Business Communication 4(7), 141-168. https://doi.org/10.1177/0021943610364523

Daft, R.L., 1978, 'A dual-core model of organisational innovation', Academy of Management Journal 21(2), 15-27. https://doi.org/10.2307/255754

Damanpour, F. \& Gopalakrishnan, S., 2001, 'The dynamics of the adoption of product and process innovations in organisations', Journal of Management Studies 38(1), 45-65. https://doi.org/10.1111/1467-6486.00227

Damanpour, F., Walker, R.M. \& Avellaneda, C.N., 2009, 'Combinative effects of innovation types and organisational performance: A longitudinal study of service
organisations', Journal of Management Studies 46(4), 650-675. https://doi. org/10.1111/j.1467-6486.2008.00814.x

Davies, M.R. \& Lewis, V.A., 1971, Models of political systems, McMillan, London.

De Vaus, D.A., 1994, Surveys in social research, UCL Press, London.

De Vos, A.S., Strydom, A., Fouche, C.B. \& Delport, C.S.L., 2005, Research at grass roots for the social science and human service professions, Van Schaik, Pretoria.

De Vries, H.A., Bekkers, V.J.J.M. \& Tummers, L., 2014, 'Innovation in the public sector: A systematic review and future research agenda', In Proceedings at the Speyer: EGPA conference, Rotterdam, April 09-11, 2014, pp. 1-30

De Wall, A.A., 2013, 'Behavioural factors important for the successful implementation and use of performance management systems', Management Decision 41(8), 688-697. https://doi.org/10.1108/00251740310496206

Dobson, P.J., 2001, 'The philosophy of critical realism: An opportunity for information systems', Information Systems Frontiers 3(2), 199-210. https://doi.org/10.1023/ A: 1011495424958

Down, B., 1999, 'How are teachers managing performance management?' AsiaPacific Journal of Teacher Education 28(3), 213-223. https://doi. org/10.1080/713650694

Dye, T.R., 1995, Understanding public policy, Prentice-Hall, Englewood.

Dzimbiri, L.B., 2008, 'Experiences in new public management in Africa: The case of performance management systems in Botswana', Africa Development XXX111(4), perform.

Edquist, C., 2001, 'Design of innovation policy through diagnostic analysis: Identification of systemic problems (or failures)', Industrial and Corporate Change 20(6), 1725-1753. https://doi.org/10.1093/icc/dtr060

Holton, J.A. \& Walsh, I., 2016, Classic grounded theory: Applications with qualitative and quantitative data, Sage, London.
Kealesitse, B., O'Mahony, G.B., Lloyd-Walker, B. \& Polonsky, M.J., 2013, 'Developing customer focused public sector reward schemes: Evidence from the Botswana government's performance reward based system (PBRS)', International Journal of Public performance reward based system (PBRS', International Journal of Public
Sector Management 26(1), 33-55. https://doi.org/10.1108/09513551311293426 Kerlinger, F.N., 1978, Foundations of behavioural research, Surjeet Publications, Delhi.

Lave, C.A. \& March, J.G., 1993, 'Trends of differentiation in baaltic magmas', American Journal of Science 25(147), 239-256.

Little, J.D.C., 2000, On model building, Massachusetts Institute of Technology, Cambridge, MA.

Liu, A., 2012, Building regression models in social sciences, viewed 13 September 2018 , from https://books.google.co.za/books?id=AWnatLAs6K8C\&pg=PA4\&dq=Buildin g+regression+models+in+social+sciences\&hl=en\&sa=X\&ved=2ahUKEwjThevN a7tAhVWQhUIHaW-Bg0Q6AEWAHoECAUQAg\#v=onepage\&q=Building $\% 2 \overline{0}$ regression\%20models\%20in\%20social\%20sciences\& $\mathrm{f}=$ false

Lund, T., 2012, 'Combining qualitative and quantitative approaches: Some arguments for mixed methods research', Scandinavian Journal of Educational Research 56(2), 155-169. https://doi.org/10.1080/00313831.2011.568674

Lynn, L.E., 1997, Public management as art, science and profession, Chatham House, Chatham, NJ.

Meeus, M. \& Edquist, C., 2006, Introduction to part 1: Product and process innovation. Innovation science and institutional change: A research handbook, Oxford University Press, Oxford.

Moore, M. \& Hartley, J., 2008, 'Innovations in governance', Public Management Review 10(1), 3-20. https://doi.org/10.1080/14719030701763161

Mouton, J. \& Marais, H.C., 1988, Metodologue van die geesteswetenskappe: Basiese begrippe, [Methodology of the humanities: Basic concepts]), HRRC Press, Pretoria.

Mulgan, G. \& Albury, D., 2003, Innovation in the public sector, Strategy Unit, London.

Mwita, J., 2000, 'Performance management model: A systems based approach to public service quality', International Journal of Public Sector Management 13(1), public service quality', International Journal of Public
19-37. https://doi.org/10.1108/09513550010334461

O'Brien, P. \& Down, B., 2002, 'What are teachers saying about new managerialism?', Journal of Educational Enquiry 3(1), 111-133.

Pollitt, C. \& Bouckaert, G., 2011, Public management reform. A comparative analysis: New public management, governance and the neo - Weberian state, Oxford University Press, London.

Pulla, V., 2016, 'An introduction to the grounded theory approach in social research', International Journal of Social Work and Human Services Practice 4(4), 75-81. https://doi.org/10.13189/ijrh.2016.040401

Quade, E.S., 1989, Analysis for public decision, Elsevier, New York, NY.

Radin, B.A., 1998, 'The Government Performance and Results Act (GPRA): Hydra-headed monster or flexible management tool?', Public Administration Review 58(4), 307-316. https://doi.org/10.2307/977560

Ramirez, A.R., 2013, The relationship between organisational culture, performance efficiency and multicultural organisation, Small Business Chron, viewed 04 July 2018, from http://smallbusiness.chron.

Riley, R.W. \& Love, L.L., 2000, 'The state of qualitative tourism research', Annals of Tourism Research 27(1), 164-187. https://doi.org/10.1016/S0160-7383(99)00068-7

Robson, P., 2002, The economics of international integration, Routledge, London.

Rock, D., Davis, J. \& Jones, B., 2014, Kill your performance ratings: Neuroscience shows why numbers based HR management is obsolete, Strategy + business, viewed 02 October 2018, from http://www.strategy-business.com.

Shim, J., Johnson, R.B., Gasson, S., Goodill, S., Jermyn, R. \& Bradt, J., 2017, 'A model of dance/movement therapy for resilience-building in people living with chronic pain', European Journal of Integrative Medicine 9, 27-40. https://doi. org/10.1016/j.eujim.2017.01.011

Shoemaker, P.J., Tankard, J.N.C. \& Lasorsa, D.L., 2004, How to build social science theories, Sage, London.

Taagepera, R., 2008, Making social sciences more scientific: The need for predictive models, Oxford University Press, New York, NY.

Tie, Y.C., Birks, M. \& Francis, K., 2019, 'Grounded theory research: A design framework for novice researchers', SAGE Open Medicine 7, 1-8. https://doi.org/10.1177/ 2050312118822927

Thompson, A.A. \& Strickland, A.J., 1995, Crafting and implementing strategy: Text and readings, Irwin, Chicago, IL.

Van der Waldt, G., 2013, 'Towards a typology of models in public administration and management as field of scientific inquiry', African Journal of Public Affairs 6(2), 38-56.

Vroom, V.H., 1964, Work and motivation, Wiley, New York, NY.

Walker, R.M., 2004, Innovation and organisational performance: A critical review and research agenda. AIM research working paper, Advanced Institute for Management Research, London.

Walker, R.M., 2014, 'Strategic management and performance in public organisations: Findings from the miles and snow frameworks', Public Administration Review 68(5), 675-685. https://doi.org/10.1111/puar.12073

Walsh, I., 2015, 'Using quantitative data in mixed-design grounded theory studies: An enhanced path to formal grounded theory in information systems', European Journal of Information Systems 5(4), 1-27. https://doi.org/10.1057/ejis.2014.23

Williams, R., 2003, Television: Technology and cultural form, Routledge, London.

Yin, R.K., 2004, Case study research: Design and methods, Sage, Thousand Oaks, CA. 